\title{
One name to rule them all: Belinurus trilobitoides (Buckland, 1837) is senior synonym to fourteen named species
}

\author{
James C. Lamsdell (1)
}

Department of Geology and Geography, West Virginia University, Morgantown, West Virginia 26501, USA <james.lamsdell@ mail.wvu.edu>

One of the oldest fossil horseshoe crabs figured in the literature is Entomolithus lunatus Martin, 1809, a Carboniferous species included in his Petrificata Derbiensia. While the species has generally been included within the genus Belinurus Bronn, 1839 , it was recently used as the type species of the new genus Parabelinurus Lamsdell, 2020. However, recent investigation as to the appropriate authority for Belinurus (see Lamsdell and Clapham, 2021) revealed that all the names in Petrificata Derbiensia were suppressed in Opinion 231 of the International Commission on Zoological Nomenclature (1954) for being consistently nonbinomial under Article 11.4 of the International Code of Zoological Nomenclature (ICZN) (International Commission on Zoological Nomenclature, 1999). Despite the validation of several species names for anthozoans, brachiopods, and cephalopods described in Petrificata Derbiensia in subsequent rulings (International Commission on Zoological Nomenclature, 1956a, b), Belinurus lunatus has not been the subject of any subsequent Commission ruling or opinion, and so its use in Petrificata Derbiensia remains suppressed. The Belinurus lunatus species name was used in several subsequent publications during the 1800 s, none of which made the name available under ICZN article 11.5; Parkinson (1811) is also suppressed for being nonbinomial, while Woodward (1830), Buckland (1837), Bronn (1839), and Baily (1859) refer to the species only as a synonym of Belinurus trilobitoides (Buckland, 1837) through citation to the suppressed Pretificata Derbiensia. The first author to make Belinurus lunatus an available name was Baldwin (1905), who used the name in reference to a new figured specimen from Sparth Bottoms, Rochdale, UK, but again as an explicit junior synonym of Belinurus trilobitoides (Buckland, 1837). Therefore, it was not until Eller (1938) treated B. lunatus as a distinct species from B. trilobitoides that $B$. lunatus became an available name as per ICZN Article 11.6.1 under the authorship of Baldwin (1905) following ICZN Article 50.7.

When Eller (1938) made B. lunatus available, he did so seemingly unwittingly, with no reference to distinguishing characteristics. Belinurus lunatus is furthermore noticeably absent from otherwise comprehensive species lists (e.g., Raymond, 1944; Morris, 1980). Prantl and Přibyl (1955) correctly listed $B$. lunatus as a synonym of $B$. bellulus (itself a junior synonym of B. trilobitoides); Filipiak and Krawczyński (1996) deferred to (but did not reiterate) Prantl and Přibyl's (1955) synonymy, but incorrectly retained B. lunatus under Martin (1809) as the senior species. Belinurus lunatus, therefore, is and always has been a junior synonym of $B$. trilobitoides.
Lamsdell (2020) and Bicknell and Pates (2020) both erroneously included $B$. lunatus as a valid species, referring particularly to Filipiak and Krawczyński's (1996) treatment of the species. In coding the species for phylogenetic analysis, Lamsdell $(2016,2020)$ referred extensively to Filipiak and Krawczyński's (1996) material, which incidentally comprises predominantly large individuals. On the basis of the resulting tree topology, Lamsdell proposed the new genus Parabelinurus, with $P$. lunatus (Martin) as the type species. As P. lunatus and $B$. trilobitoides are synonyms, Parabelinurus Lamsdell, 2020 and Belinurus Bronn, 1839 are objective synonyms. Thirteen other Belinurus species have also been proposed as synonyms with B. trilobitoides, with their constituent specimens representing taphonomic or ontogenetic variants (Fisher, 1975; Anderson, 1996; Haug and Haug, 2020), including the type species of further genera considered valid by Lamsdell (2020), Koenigiella Raymond, 1944 and Macrobelinurus Lamsdell, 2020. To clarify this issue for future researchers, a full taxonomic history of Belinurus trilobitoides (Buckland, 1837), including all synonymies, is presented here.

\section{Systematic paleontology}

\section{Belinurus Bronn, 1839}

(= Bellinurus Pictet, 1846; = Steropis Baily, 1859; = Koenigiella Raymond, 1944; = Macrobelinurus Lamsdell, 2020; = Parabelinurus Lamsdell, 2020)

Type species.—Limulus trilobitoides (Buckland, 1837), by subsequent designation (= Belinurus bellulus König, c.1851/ Pictet, 1854; = Steropis arcuatus Baily, 1859; = Belinurus reginae Baily, 1863; = Belinurus koenigianus Woodward, 1872; = Bellinurus grandaevus Jones and Woodward, 1899; = Parabelinurus lunatus (Baldwin, 1905); = Bellinurus baldwini Woodward, 1907; = Bellinurus longicaudatus Woodward, 1907; = Bellinurus trechmanni Woodward, 1918; = Belinurus concinnus Dix and Pringle, 1929;=Belinurus carwayensis Dix and Pringle, 1929; = Belinurus truemani Dix and Pringle, 1929;=Belinurus pustulosus Dix and Pringle, 1929; = Belinurus morgani Dix and Pringle, 1930).

Other species.—?Belinurus iswariensis (Chernyshev, 1928); ?Belinurus kiltorcanensis Baily, 1869; Belinurus lacoei (Packard, 1885); ?Belinurus metschensis (Chernyshev, 1928); Belinurus silesiacus (Roemer, 1883); ?Belinurus stepanovi (Chernyshev, 1928); Belinurus sustai (Prantl and Přibyl, 1955). 
Diagnosis.-Belinurid with ophthalmic spines positioned at posterior of ophthalmic ridges; axis of first thoracetron tergite medially inflated; thoracetron ovoid to semicircular in outline; thoracetron fixed tergopleural spines elongate, needle-like; conical opisthosomal boss present (after Lamsdell, 2020).

Remarks. - The correct authorship and spelling of Belinurus was recently clarified by Lamsdell and Clapham (2021), who demonstrated that Belinurus Bronn, 1839 was the correct spelling and attribution as opposed to Bellinurus Pictet, 1846.

?Belinurus kiltorcanensis is known only from an isolated carapace that exhibits ophthalmic ridges similar to those in $\mathrm{Bel}$ linuroopsis and may not be a Belinurus. The Belinurus species described by Chernyshev (1928) need restudy to ascertain their placement within the genus.

\section{Belinurus trilobitoides (Buckland, 1837)} Figure 1

1809 'Entomolithus Monoculites? (lunatus)'; Martin, p. 191, pl. 45 , fig. 4.

1811 'Monoculites lunatus'; Parkinson, p. 275, pl. 18, fig. 18.

1830 'Entomolithus Derbyensis lunatus'; Woodward, p. 8.

1837 Limulus trilobitoides Buckland, p. 77, pl. 46", fig. 3.

1839 'Belinurus monoculites'; Bronn, p. 489.

1839 Belinurus trilobitoides; Bronn, p. 489.

1840 Limulus trilobitoides; Prestwich, p. 491, pl. 41, fig. 8.

1843 Limulus trilobitoides; Morris, p. 75.

1850 Limulus trilobitoides; Mantell, p. 156, pl. 68, fig. 15.

c.1851 Belinurus bellulus König, pl. 28, fig. 230.

1854 Bellinurus bellulus; Pictet, p. 538, pl. 46, fig. 23.

1859 Steropis arcuatus Baily, p. 90.

1859 Steropis trilobitoides; Baily, p. 91.

1859 'Steropis monoculus'; Baily, p. 91.

1859 Steropis bellulus; Baily, p. 91.

1863 Belinurus reginae Baily, p. 110, pl. 5, fig. 1A-D.

1863 Belinurus arcuatus; Baily, p. 111, pl. 5, fig. 2A-C.

1867 Belinurus trilobitoides; Woodward, p. 32.

1867 Belinurus reginae; Woodward, p. 32, pl. 1, fig. 1.

1867 Belinurus arcuatus; Woodward, p. 32.

1872 Limulus trilobitoides; Woodward, p. 439.

1872 Bellinurus bellulus; Woodward, p. 439.

1872 Bellinurus reginae; Woodward, p. 439.

1872 Bellinurus arcuatus; Woodward, p. 439.

1872 Bellinurus koenigianus Woodward, p. 439, pl. 10, fig. 8.

1878 Bellinurus bellulus; Woodward, p. 239, pl. 31, fig. 3a-c.

1878 Bellinurus reginae; Woodward, p. 240, pl. 31, fig. 1a-d.

1878 Bellinurus arcuatus; Woodward, p. 241, pl. 31, fig. 2a, b.

1878 Bellinurus koenigianus; Woodward, p. 243, pl. 31, figs. 3c, 4.

1899 Bellinurus grandaevus Jones and Woodward, p. 388, pl. 15, figs. 2, 3 .

1903 Belinurus bellulus; Baldwin, p. 198.

1905 Belinurus lunatus Baldwin, p. 136, fig. 2.

1907 Belinurus lunatus; Parker, p. 44.

1907 Bellinurus baldwini Woodward, p. 540, fig. 1.

1907 Bellinurus longicaudatus Woodward, p. 451, fig. 2.

1908 Belinurus baldwini; Parker, p. 71.
1908

1909

1909

1911

1918

1929

1929

1929

1929

1929

1929

1929

1929

1930

1930

1930

1930

1930

1930

1930

1930

1938

1938

1938

1938

1938

1938

1938

1938

1938

1938

1938

1938

1938

1938

1944

1944

1944

1944

1944

1944

1944

1944

1944

1951

1952

1952

1955

1955

1955

1955

1957

1957

1975

1980

1980

1980

1980
Belinurus longicaudatus; Parker, p. 72.

Belinurus baldwini; Parker, p. 6.

Belinurus longicaudatus; Parker, p. 6.

Belinurus reginae; Pruvost, p. 299, pl. 7, fig. 4, 4a.

Bellinurus trechmanni Woodward, p. 462, fig. 5.

Belinurus concinnus Dix and Pringle, p. 92, fig. 1.

Belinurus carwayensis Dix and Pringle, p. 93, fig. 2.

Belinurus truemani Dix and Pringle, p. 94, fig. 3.

Belinurus pustulosus Dix and Pringle, p. 95, fig. 4.

Belinurus bellulus; Dix and Pringle, p. 97, fig. 5.

Belinurus arcuatus; Dix and Pringle, p. 98, fig. 6.

Belinurus cf. B. arcuatus; Dix and Pringle, p. 99, fig. 7.

Belinurus cf. B. koenigianus; Dix and Pringle, p. 100, fig. 8.

Belinurus reginae; Pruvost, p. 197, pl. 12, fig. 5.

Belinurus lunatus; Pruvost, p. 198, pl. 12, figs. 7, 8.

Belinurus koenigi; Pruvost, p. 199, pl. 12, fig. 6.

Belinurus morgani Dix and Pringle, p. 137, fig. 1.

Belinurus cf. B. truemani; Dix and Pringle, p. 138, fig. 2.

Belinurus bellulus; Dix and Pringle, p. 139, fig. 3.

Belinurus konigianus; Dix and Pringle, p. 141.

Belinurus reginae; Dix and Pringle, p. 141.

Belinurus bellulus; Eller, p. 132, p. 10, figs. 3-10.

Belinurus koenigianus; Eller, p. 132, pl. 9, fig. 3, pl 11., figs. 1, 2, 8 .

Belinurus grandaevus; Eller, p. 132, pl.12, figs. 7, 8.

Belinurus pustulosus; Eller, p. 133, pl. 12, fig. 9.

Belinurus reginae; Eller, p. 133, pl. 10, figs. 1, 2.

Belinurus arcuatus; Eller, p. 133, pl. 11, figs. 3-6.

Belinurus lunatus; Eller, p. 133, pl. 14, fig. 3.

Belinurus baldwini; Eller, p. 133, pl. 14, fig. 1.

Belinurus longicaudatus; Eller, p. 133, pl. 14, fig. 2.

Belinurus truemanni; Eller, p. 134, pl. 11, fig. 7.

Belinurus concinnus; Eller, p. 134, pl. 12, fig. 5.

Belinurus carwayensis; Eller, p. 134, pl. 12, fig. 6.

Belinurus morgani; Eller, p. 134, pl. 12, fig. 2.

Belinurus trechmanni; Eller, pl. 12, fig. 1.

Belinurus concinnus; Raymond, p. 480.

Belinurus grandaevus; Raymond, p. 480.

Belinurus bellulus; Raymond, p. 480.

Belinurus truemani; Raymond, p. 480.

Belinurus morgani; Raymond, p. 480.

Belinurus pustulosus; Raymond, p. 480.

Koenigiella reginae; Raymond, p. 480.

Koenigiella arcuata; Raymond, p. 480.

Koenigiella koenigiana; Raymond, p. 480.

Belinurus reginae; van der Heide, pl. 7, figs. 2, 5.

Belinurus reginae; Størmer, p. 635.

Belinurus bellulus; Størmer, p. 635.

Belinurus regina; Størmer, p. 20, fig. 13.1a.

Belinurus arcuatus; Størmer, p. 20, fig. 13.1b.

Belinurus baldwini; Størmer, p. 20, fig. 13.1c.

Belinurus bellulus; Prantl and Přibyl, p. 385, pl. 1, figs. 1, 2.

Belinurus reginae; Copeland, p. 48, pl. 16, figs. 2, 9, 10.

Belinurus grandaevus; Copeland, p. 48, pl. 16, figs. 1, 3-8.

Belinurus koenigianus; Bergström, p. 294, pl. 1, fig. 5.

Belinurus bellulus; Morris, p. 31.

Bellinurus baldwini; Morris, p. 31.

Bellinurus koenigianus; Morris, p. 31.

Bellinurus longicaudatus; Morris, p. 31. 

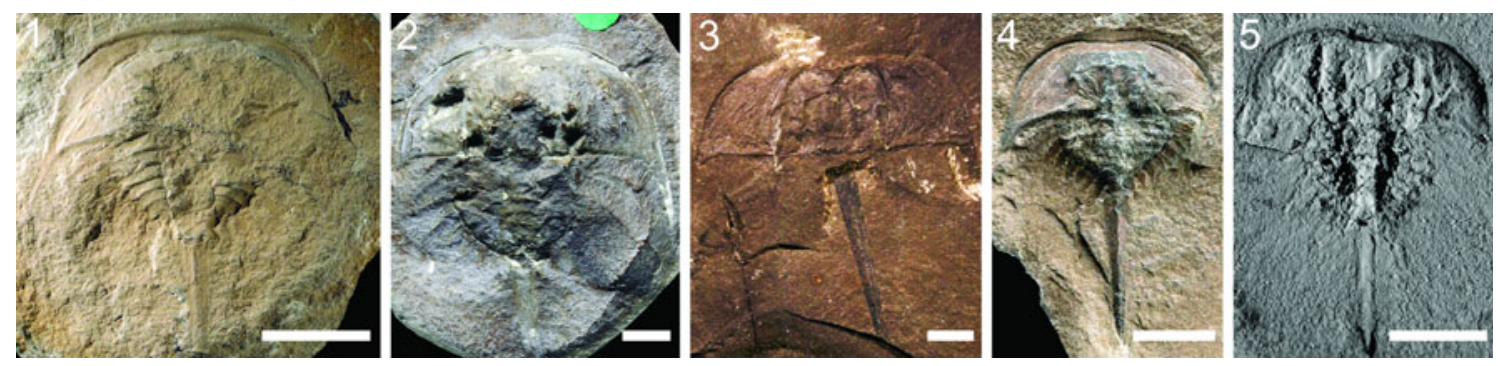

Figure 1. Specimens of Belinurus trilobitoides previously considered to represent distinct species and genera. (1) MM LL.111267a, assigned to Belinurus trilobitoides. (2) NHMUK PI. I. 2754, previously assigned to Belinurus lunatus. (3) GSC 12803, previously assigned to Belinurus reginae. (4) NHMUK PI. In. 18572, holotype of Belinurus baldwini. (5) AM F29886, previously assigned to Belinurus arcuatus. Scale bars $=5 \mathrm{~mm}$. Institutional abbreviations: AM = Australian Museum, Sydney, Australia; GSC = Geological Survey of Canada, Ottawa, Canada; MMUP = Manchester Museum, Manchester, UK; NHMUK = Natural History Museum, London, UK. $(\mathbf{1}, \mathbf{2}, \mathbf{4}, \mathbf{5})$ Images reproduced from Bicknell and Pates $(2020)$ under a CC BY 4.0 license.

1980 Bellinurus trilobitoides; Morris, p. 31.

1981 Belinurus koenigianus; Fisher, p. 51, fig. 3A.

1984 Belinurus reginae; Fisher, p. 199.

1984 Belinurus bellulus; Fisher, p. 199.

1984 Belinurus koenigianus; Fisher, p. 199.

1987 Bellinurus koenigianus; Selden and Siveter, p. 384.

1994 Bellinurus grandaevus; Schultka, p. 347.

1994 Bellinurus arcutus; Schultka, p. 347.

1994 Bellinurus reginae; Schultka, p. 347.

1994 Bellinurus lunatus; Schultka, p. 347.

1994 Bellinurus concinnus; Schultka, p. 347.

1994 Bellinurus longicaudatus; Schultka, p. 347.

1994 Bellinurus koenigianus; Schultka, p. 347.

1994 Bellinurus baldwinii; Schultka, p. 347.

1994 Bellinurus bellulus; Schultka, p. 347.

1994 Bellinurus carwayensis; Schultka, p. 347.

1994 Bellinurus morganii; Schultka, p. 347.

1994 Bellinurus truemanii; Schultka, p. 347.

1994 Bellinurus trechmannii; Schultka, p. 347.

1996 Bellinurus lunatus; Filipiak and Krawczyński, p. 420, fig. 4C-H.

1997 Bellinurus truemani; Anderson and Selden, p. 20.

1997 Bellinurus morgani; Anderson and Selden, p. 20.

1997 Bellinurus koenigianus; Anderson and Selden, p. 20.

1997 Bellinurus trilobitoides; Anderson and Selden, p. 20, fig. 1.

1997 Bellinurus arcuatus; Anderson and Selden, p. 20.

1997 Bellinurus trilobitoides; Anderson et al., p. 203, fig. 4a, b.

2016 Bellinurus arcuatus; Lamsdell, p. 182.

2016 Bellinurus bellulus; Lamsdell, p. 182.

2016 Bellinurus lunatus; Lamsdell, p. 182.

2016 Bellinurus reginae; Lamsdell, p. 182.

2016 Bellinurus trilobitoides; Lamsdell, p. 182.

2016 Bellinurus truemanii; Lamsdell, p. 182.

2020 Bellinurus arcuatus; Bicknell and Pates, p. 18, fig. 13C. 2020 Bellinurus baldwini; Bicknell and Pates, p. 18, fig. 13E. 2020 Bellinurus bellulus; Bicknell and Pates, p. 18, fig. 13D. 2020 Bellinurus carwayensis; Bicknell and Pates, p. 18, fig. 13F. 2020 Bellinurus concinnus; Bicknell and Pates, p. 18, fig. 14B.

2020 Bellinurus koenigianus; Bicknell and Pates, p. 18, fig. 14E. 2020 Bellinurus longicaudatus; Bicknell and Pates, p. 18, fig. $15 \mathrm{C}$.

2020 Bellinurus lunatus; Bicknell and Pates, p. 18, fig. 15A, B. 2020 Bellinurus pustulosus; Bicknell and Pates, p. 18, fig. 16D. 2020 Bellinurus reginae; Bicknell and Pates, p. 19, fig. 16C, E.
2020 Bellinurus trechmanni; Bicknell and Pates, p. 19, fig. 17B.

2020 Bellinurus trilobitoides; Bicknell and Pates, p. 19, fig. 17D.

2020 Bellinurus truemani; Bicknell and Pates, p. 19, fig. 17C.

2020 'Belinurus sp.'; Haug and Haug, figs. 1I-VI, 3, 4, 5, $8 \mathrm{a}-\mathrm{f}, 10 \mathrm{a}-\mathrm{c}$.

2020 Belinurus bellulus; Lamsdell, p. 13.

2020 Belinurus carwayensis; Lamsdell, p. 13, fig. 1G.

2020 Belinurus concinnus; Lamsdell, p. 13.

2020 Belinurus grandaevus; Lamsdell, p. 13.

2020 Belinurus morgani; Lamsdell, p. 13, fig. 1J.

2020 Belinurus pustulosus; Lamsdell, p. 13.

2020 Belinurus trechmanni; Lamsdell, p. 14.

2020 Belinurus trilobitoides; Lamsdell, p. 14.

2020 Koenigiella reginae; Lamsdell, p. 14.

2020 Koenigiella baldwini; Lamsdell, p. 15.

2020 Koenigiella koenigianus; Lamsdell, p. 15.

2020 Koenigiella longicaudatus; Lamsdell, p. 15.

2020 Koenigiella truemani; Lamsdell, p. 15.

2020 Macrobelinurus arcuatus; Lamsdell, p. 15.

2020 Parabelinurus lunatus; Lamsdell, p. 15.

Lectotype.-Complete individual preserving dorsal exoskeleton, comprising prosomal carapace, thoracetron, and telson (BNMH 34889) from the Carboniferous clay ironstone of the Coalbrookdale Coal Measures, Telford, Shropshire (Buckland, 1837, pl. 46", fig. 3).

Remarks.-Fifteen of the 22 species historically included within Belinurus have been considered synonyms after critical evaluation by a number of researchers (Fisher, 1975; Anderson, 1996), with many regularly co-occurring (e.g., $B$. reginae and $B$. grandaevus in Nova Scotia, Canada (Copeland, 1957); B. arcuatus and B. reginae in Leinster, Ireland (Baily, 1863); B. trilobitoides, B. lunatus, B. longicaudatus, and B. baldwini in Rochdale, UK (Eller, 1938); B. morgani, B. trilobitoides, and B. reginae in Neath, Wales (Dix and Pringle, 1930)). Haug and Haug (2020), in reconstructing an ontogenetic series of Belinurus specimens based on material held in the Natural History Museum, London $(\mathrm{BMNH})$, did not refer to the previous species assignments of individual specimens but included numerous specimens referred to B. trilobitoides (BMNH 18357, 18565, 18571, 36188, 13897, 13898, 13958, In41494, 46421) along with the holotypes of B. baldwini (BMNH 
In18572), $B$. koenigianus (BMNH In59227), and $B$. trechmanni (BMNH In18487) as different ontogenetic stages of the same species.

Most of the 14 junior synonyms of $B$. trilobitoides were diagnosed on the basis of dubious morphological criteria that are now known to be the result of taphonomic or ontogenetic processes, a conclusion supported by recent increases in our understanding of horseshoe crab decay (Babcock and Chang, 1997) and development (Haug et al., 2012; Haug and Rötzer, 2018; Tashman et al., 2019; Haug and Haug, 2020; Lamsdell, 2021). Belinurus arcuatus (the type species of Macrobelinurus Lamsdell, 2020), known from an isolated carapace, was diagnosed on the basis of the presence of a "facial suture" that is actually a crease in a taphonomically deformed specimen that otherwise exhibits no clear differences from specimens of $B$. trilobitoides. Belinurus reginae (type species of Koenigiella Raymond, 1944) was diagnosed solely on the occurrence of long thoracetron epimera, a trait known to vary throughout ontogeny. Belinurus koenigianus was diagnosed on the basis of the lack of carapace spines (which are actually broken away from the specimen rather than absent) and the proportions of the thoracetron, which is laterally compressed. No diagnosis was presented for B. grandaevus, which appears to have been named solely due to its geographic occurrence, and the available material shows no obvious differences from $B$. trilobitoides. Baldwin (1905) explicitly named $B$. lunatus as a junior synonym of $B$. trilobitoides and as such provided no diagnostic differences. Belinurus baldwini was defined as a species on the basis of carapace dimensions; however, the type specimen is taphonomically distorted and no other characters separate it from B. trilobitoides. Belinurus longicaudatus was diagnosed solely on its possession of a long telson although telson length is known to vary between individuals and through ontogeny. Belinurus trechmanni is known from a small specimen and diagnosed on the basis of genal spine length and thoracetron shape, both of which change through ontogeny. Finally, Dix and Pringle $(1929,1930)$ named $B$. concinnus, B. carwayensis, B. truemanni, and B. morgani on the basis of their possession of different numbers of free segments in the thoracetron, an interpretation of segment articulation now recognized as erroneous (Anderson and Selden, 1997). Belinurus truemanni was further diagnosed by the possession of curved genal spines (the form of which is due to compression), $B$. concinnus by a long headshield (when the specimen is tectonically distorted), and B. morgani by granulation on the prosoma (which is also known from $B$. trilobitoides). The final synonymous species, B. pustulosus, was diagnosed on the basis of a pustulose cuticular ornament, which again does not serve to distinguish the specimens from $B$. trilobitoides. With none of these species having valid diagnostic traits to separate them from $B$. trilobitoides, the weight of evidence suggests that all are considered synonyms, in keeping with the conclusions of Fisher (1975), Anderson (1996), and Haug and Haug (2020).

\section{Acknowledgments}

I am grateful to L. Babcock and C. Schweitzer for their reviews of the manuscript. I thank R. Bicknell for providing a copy of Prantl and Přibyl (1955).

\section{References}

Anderson, L.I., 1996, Taphonomy and taxonomy of Palaeozoic Xiphosura [Ph.D. dissertation]: Manchester, University of Manchester, 347 p.

Anderson, L.I., and Selden P.A., 1997, Opisthosomal fusion and phylogeny of Palaeozoic Xiphosura: Lethaia, v. 30, p. 19-31.

Anderson, L.I., Dunlop, J.A., Horrocks, C.A., Winkelmann, H.M., and Eager, R.M.C., 1997, Exceptionally preserved fossils from Bickershaw, Lancashire UK (upper Carboniferous, Westphalian A (Langsettian)): Geological Journal, v. 32, p. 197-210.

Babcock, L.E., and Chang., W., 1997, Comparative taphonomy of two nonmineralized arthropods: Naraoia (Nektaspida; early Cambrian, Chengjiang Biota, China) and Limulus (Xiphosurida; Holocene, Atlantic Ocean): Bulletin of National Museum of Natural Science, v. 10, p. 233-250.

Baily, W.H., 1869, On a crustacean from the coal-measures, with some remarks on the genus Limulus: Journal of the Geological Society of Dublin, v. 8, p. 89-91.

Baily, W.H., 1863, Remarks on some Coal Measures Crustacea belonging to the genus Belinurus, König, with description of two new species from Queen's County, Ireland: Annals and Magazine of Natural History, v. 11, p. 107114.

Baily, W.H., 1869, On fossils obtained at Kiltorcan Quarry, Co. Kilkenny: British Association Report, v. 39, p. 73-75.

Baldwin, W., 1903, Bellinurus bellulus, from Sparth, Rochdale: Transactions of the Manchester Geological Society, v. 28, p. 198-202.

Baldwin, W., 1905, Prestwichia anthrax and Belinurus lunatus from Sparth Bottoms, Rochdale: Transactions of the Manchester Geological Society, v. 29 , p. $124-128$.

Bergström, J., 1975, Functional morphology and evolution of xiphosurids: Fossils and Strata, v. 4, p. 291-305.

Bicknell, R.D.C., and Pates, S., 2020, Pictorial atlas of fossil and extant horseshoe crabs, with focus on Xiphosurida: Frontiers in Earth Science, v. 9, n. 98, https://doi.org/10.3389/feart.2020.00098

Bronn, H.G., 1839, Fossile Limulus-arten: Neues Jarhbuch für Mineralogie, Geognosie, Geologie und Petrefaktenkunde, v. 1839, p. 489-490.

Buckland, W., 1837, The Bridgewater Treatises on the Power, Wisdom and Goodness of God as Manifested in the Creation. Treatise IV. Geology and Mineralogy with Reference to Natural Theology (second edition): London, William Pickering, $316 \mathrm{p}$.

Chernyshev, B.I., 1928, Nouvelles données sur les Xiphosura du basin Donetz: Bulletin du Comité Géologique, v. 47, p. 519-531.

Copeland, M.J., 1957, The arthropod fauna of the upper Carboniferous rocks of the maritime provinces: Geological Survey of Canada Memoir, v. 286, 110 p.

Dix, E., and Pringle, J., 1929, On the fossil Xiphosura from the South Wales Coalfield with a note on the myriapod Euphoberia: Summary of Progress, Geological Survey of Great Britain, v. 1928, p. 90-113.

Dix, E., and Pringle, J., 1930, Some coal measure arthropods from the South Wales Coalfield: Annals and Magazine of Natural History, v. 6, p. 136-144.

Eller, E.R., 1938, A review of the xiphosuran genus Belinurus with the description of a new species, B. allegayensis: Annals of the Carnegie Museum, v. 27, p. $129-150$.

Filipiak, P., and Krawczyński, W., 1996, Westphalian xiphosurans (Chelicerata) from the Upper Silesia Coal Basin of Sosnowiec, Poland: Acta Palaeontologica Polonica, v. 41, p. 413-425.

Fisher, D.C., 1975, Evolution and functional morphology of the Xiphosurida [Ph.D. dissertation]: Cambridge, Massachusetts, Harvard University, 393 p.

Fisher, D.C., 1981, The role of functional analysis in phylogenetic inference: examples from the history of the Xiphosura: American Zoologist, v. 21, p. $47-62$.

Fisher, D.C., 1984, The Xiphosurida: archetypes of bradytely? in Eldredge, N., and Stanley, S.M., eds., Living Fossils: New York, Springer Verlag, p. 196213.

Haug, C., and Haug, J.T., 2020, Untangling the Gordian knot-further resolving the superspecies complex of 300-million-year-old xiphosurids by reconstructing their ontogeny: Development Genes and Evolution, v. 230, p. 13 26.

Haug, C., and Rötzer, M.A.I.N., 2018, The ontogeny of the 300 million year old xiphosuran Euproops danae (Euchelicerata) and implications for resolving the Euproops species complex: Development Genes and Evolution, v. 228, p. 63-74.

Haug, C., Van Roy, P., Leipner, A., Funch, P., Rudkin, D.M., Schöllman, L., and Haug, J.T., 2012, A holomorph approach to xiphosuran evolution-a case study on the ontogeny of Euproops: Development Genes and Evolution, v. 222, p. 253-268.

International Commission on Zoological Nomenclature, 1954, Opinion 231. Rejection for nomenclatural purposes of Martin (W.), 1793, Figures and Descriptions of Petrifactions collected in Derbyshire and of the work by the same author published in 1809 under the title Petrificata Derbiensia: 
Opinions and Declarations Rendered by the International Commission on Zoological Nomenclature, v. 4, p. 239-248.

International Commission on Zoological Nomenclature, 1956a, Opinion 419. Validation under the Plenary Powers of the names published by William Martin in 1809 in the work entitled Petrificata Derbiensia for eight species of the class Brachiopoda and for two species of the class Anthozoa and matters incidental thereto: Opinions and Declarations Rendered by the International Commission on Zoological Nomenclature, v. 14, p. 69-128.

International Commission on Zoological Nomenclature, 1956b, Opinion 420. Addition to the Official List of Specific Names in Zoology of the specific names for eleven species of the class Brachiopoda and for two species of the class Cephalopoda originally published by Martin (W.) in 1809 in the nomenclatorially invalid work entitled Petrificata Derbiensia and now available as from the first subsequent date on which they were severally published in conditions satisfying the requirements of the Règles: Opinions and Declarations Rendered by the International Commission on Zoological Nomenclature, v. 14, p. 129-168.

International Commission on Zoological Nomenclature, 1999, International Code of Zoological Nomenclature (fourth edition): London, International Trust for Zoological Nomenclature, $306 \mathrm{p}$.

Jones, T.R., and Woodward, H., 1899, Contributions to fossil Crustacea: Geological Magazine, v. 6, p. 388-395.

König, C., c. 1851, Icones fossilium sectiles pls. 9-19: ?London.

Lamsdell, J.C., 2016, Horseshoe crab phylogeny and independent colonisations of freshwater: ecological invasion as a driver for morphological innovation: Palaeontology, v. 59, p. 181-194.

Lamsdell, J.C., 2020, The phylogeny and systematics of Xiphosura: PeerJ, v. 8, e10431, https://doi.org/10.7717/peerj.10431

Lamsdell, J.C., 2021, A new method for quantifying heterochrony in evolutionary lineages: Paleobiology, v. 47, p. 363-384.

Lamsdell, J.C., and Clapham, M.E., (2021), Belinurus Bronn, 1839 (Chelicerata, Xiphosura) has priority over Bellinurus Pictet, 1846: Journal of Paleontology, https://doi.org/10.1017/jpa.2021.53

Mantell, G.A., 1850, A Pictorial Atlas of Fossil Remains, Consisting of Coloured Illustrations Selected from Parkinson's "Organic remains of a former world" and Artis's "Antediluvian phytology": London, Henry G. Bohn, 207 p.

Martin, W., 1809, Petrificata Derbiensia; Or Figures and Descriptions of Petrifactions Collected in Derbyshire: Wigan, D. Lyon, $251 \mathrm{p}$.

Morris, J., 1843, A Catalogue of British Fossils: London, British Museum (Natural History), $222 \mathrm{p}$

Morris, S.F., 1980, Catalogue of the Type and Figured Specimens of Fossil Crustacea (excl. Ostracoda), Chelicerata, Myriapoda and Pycnogonida in the British Museum (Natural History): London: British Museum (Natural History), 53 p.

Packard, A.S., 1885, Types of Carboniferous Xiphosura new to North America: American Naturalist, v. 1885, p. 291-294.

Parker, W.A., 1907, Belinurus lunatus (Martin) from middle coal measures of Sparth, Rochdale: The Lancashire Naturalist, v. 12, p. 44-45.

Parker, W.A., 1908, Fossil Arthropoda and Pisces from the middle coal measures of Sparth, Rochdale: Transactions of the Rochdale Literary and Scientific Society, v. 9, p. 64-76.

Parker, W.A., 1909, The fossil Arthropoda and Pisces of Sparth, Rochdale: The Lancashire Naturalist, v. 14, p. 2-8.

Parkinson, J., 1811, Organic Remains of a Former World. An Examination of the Mineralized Remains of the Vegetables and Animals of the Antediluvian World; Generally Termed Fossils, Volume III: The Fossil Starfish, Echini, Shells, Insects, Amphibia, Mammalia, \&c: London, Sherwood, Neely, and Jones, $479 \mathrm{p}$.
Pictet, F.J., 1846, Traite élémentaire de paléontologie, Volume 4: Paris, Langlois et Leclerq, $371 \mathrm{p}$

Pictet, F.J., 1854, Traite élémentaire de paléontologie, Volume 2 (second edition): Paris, Bailliere, $727 \mathrm{p}$.

Prantl, F., and Přibyl, A., 1955, Ostrorepi (Xiphosura) ceskoslovenskeho karbonu: Sborník Ústředního ústavu geologického, v. 22, p. 379-424.

Prestwich, J., 1840, Memoir on the geology of the Coalbrook Dale: Transactions of the Geological Society of London, v. 5, p. 413-495.

Pruvost, P., 1911, Note sur quelques crustacés (Prestwichia, Belinurus et Eurypterus) du terrain houiller du Nord de la France: Annales de la Société géologique du Nord, v. 40, p. 295-302.

Pruvost, P., 1930, Description de la faune continentale du terrain houiller de la Belgique: Memoirs of the Royal Belgium Museum of Natural Sciences, v. 44 , p. $111-282$

Raymond, P.E., 1944, Late Paleozoic xiphosurans: Bulletin of the Museum of Comparative Zoology, v. 64, p. 475-508.

Roemer, F., 1883, Über eine Art der limuliden-gattung Belinurus aus dem Steinkohlengebirge Oberschlesiens: Zeitschrift der Deutschen Geologischen Gesellschaft, v. 35, p. 429-432.

Schultka, S., 1994, Bellinurus cf. truemanii (Merostomata) aus dem tiefen Oberkarbon (Namur B/C) von Fröndenberg (Nordrhein-Westfalen, Germany): Paläontologische Zeitschrift, v. 68, p. 339-349.

Selden, P.A., and Siveter, D.J., 1987, The origin of the limuloids: Lethaia, v. 20, p. 383-392.

Størmer, L., 1952, Phylogeny and taxonomy of fossil horseshoe crabs: Journal of Paleontology, v. 26, p. 630-640.

Størmer, L., 1955, Merostomata, in Moore, R., ed. Treatise on Invertebrate Paleontology, Part P, Arthropoda 2: Boulder, Colorado, and Lawrence, Kansas, Geological Society of America and University of Kansas Press, p. P4-P41.

Tashman, J.N., Feldmann, R.M., and Schweitzer, C.E., 2019, Morphological variation in the Pennsylvanian horseshoe crab Euproops danae (Meek \& Worthen, 1865) (Xiphosurida, Euproopidae) from the lower Mercer Shale, Windber, Pennsylvania, USA: Journal of Crustacean Biology, v. 39, p. 396-406.

van der Heide, S., 1951, Les Arthropodes du terrain houiller du Limbourg Méridional (excepté les scorpions et les insectes): Mededeelingen van de Geologische Stichting Serie C-IV-3, v. 3, 84 p.

Woodward, H., 1867, On some points in the structure of the Xiphosura, having reference to their relationship with the Eurypteridae: Quarterly Journal of the Geological Society of London, v. 23, p. 28-37.

Woodward, H., 1872, Notes on some British Palaeozoic Crustacea belonging to the order Merostomata: Geological Magazine, v. 9, p. 433-441.

Woodward, H., 1878, A monograph of the British fossil Crustacea belonging to the order Merostomata: Monograph of the Palaeontographical Society, London, v. 19, 22, 26, 32, $263 \mathrm{p}$.

Woodward, H., 1907, Further notes on the Arthropoda of the British Coal Measures: Geological Magazine, v. 4, p. 539-549.

Woodward, H., 1918, Fossil arthropods from the Carboniferous rocks of Cape Breton, Nova Scotia; and from the Upper Coal Measures, Sunderland, England: Geological Magazine, v. 5, p. 462-471.

Woodward, S., 1830, A Synoptic Table of British Organic Remains: London, Longman, Rees, Orme, Brown, and Green, $50 \mathrm{p}$.

Accepted: 31 July 2021 